\title{
Epilobium angustifolium extract demonstrates multiple effects on dermal fibroblasts in vitro and skin photo-protection in vivo
}

\author{
Ema Ruszová ${ }^{1,2,3}$, José Cheel $^{1}$, Stanislav Pávek ${ }^{1}$, Martina Moravcová ${ }^{1}$, Martina Hermannová1, \\ Ilona Matějková ${ }^{1}$, Jiřina Spilková ${ }^{4}$, Vladimír Velebný ${ }^{1}$ and Lukáš Kubala ${ }^{5,6}$ \\ ${ }^{1}$ Contipro Biotech s.r.o., Dolni Dobrouc, Czech Republic \\ ${ }^{2}$ Department of Physiology and Immunology of Animals, Institute of Experimental Biology, Faculty of Science, Masaryk \\ University, Kotlarska 2, Brno, Czech Republic \\ ${ }^{3}$ Department of Clinical Genetics, Faculty Hospital, Sokolska 581, Hradec Kralove, Czech Republic \\ ${ }^{4}$ Department of Pharmacognosy, Faculty of Pharmacy, Charles University, Heyrovskeho 1203, Hradec Kralove, Czech Republic \\ ${ }^{5}$ Institute of Biophysics, Academy of Sciences of the Czech Republic, Kralovopolska 135, Brno, Czech Republic \\ ${ }^{6}$ International Clinical Research Center - Center of Biomolecular and Cellular Engineering, St. Anne's University Hospital, \\ Brno, Czech Republic
}

\begin{abstract}
Stress-induced fibroblast senescence is thought to contribute to skin aging. Ultraviolet light (UV) radiation is the most potent environmental risk factor in these processes. An Epilobium angustifolium (EA) extract was evaluated for its capacity to reverse the senescent response of normal human dermal fibroblasts (NHDF) in vitro and to exhibit skin photo-protection in vivo. The HPLC-UV-MS analysis of the EA preparation identified three major polyphenol groups: tannins (oenothein B), phenolic acids (gallic and chlorogenic acids) and flavonoids. EA extract increased the cell viability of senescent NHDF induced by serum deprivation. It diminished connective tissue growth factor and fibronectin gene expressions in senescent NHDF. Down-regulation of the UV-induced release of both matrix metalloproteinase- 1 and -3 and the tissue inhibitor of matrix metalloproteinases- 1 and -2 , and also down-regulation of the gene expression of hyaluronidase 2 were observed in repeatedly UV-irradiated NHDF after $E A$ extract treatment. Interestingly, $E A$ extract diminished the down-regulation of sirtuin 1 dampened by UV-irradiation. The application of $E A$ extract using a sub-irritating dose protected skin against UV-induced erythema formation in vivo. In summary, EA extract diminished stress-induced effects on NHDF, particularly on connective tissue growth factor, fibronectin and matrix metalloproteinases. These results collectively suggest that $E A$ extract may possess anti-aging properties and that the EA polyphenols might account for these benefits.
\end{abstract}

Key words: Epilobium angustifolium (Onagraceae) - Ultraviolet light - Metalloproteinase - Hyaluronidase

\begin{abstract}
Abbreviations: ABAP, 2,2'-azobis(2-amidinopropane) dihydrochloride; CTGF, connective tissue growth factor; EA, Epilobium angustifolium; ECM, extracellular matrix; FBS, fetal bovine serum; HA, hyaluronic acid; Hyal, hyaluronidase; MMP, matrix metalloprotease; MS, mass spectrometry; PBS, phosphate buffered saline; SIRT-1, Sirtuin 1; TIMP, tissue inhibitor of matrix metalloprotease; TRAP, total reactive antioxidant potential; UV, ultraviolet light.
\end{abstract}

Electronic supplementary material. The online version of this article (doi: 10.4149/gpb_2013031) contains Supplementary material.

Correspondence to: Ema Ruszová, Department of Clinical Genetics, Faculty Hospital, Sokolska 581, 50005 Hradec Kralove, Czech Republic

E-mail: ema.ruszova@fnhk.cz
Lukáš Kubala, Institute of Biophysics, Academy of Sciences of the Czech Republic, Kralovopolska 135, 61265 Brno, Czech Republic E-mail: kubalal@ibp.cz 


\section{Introduction}

Skin photoaging (extrinsic aging) is primarily induced by the exposure of skin to solar radiation, particularly to the ultraviolet (UV) part of the spectrum (Kim et al. 2004). The detrimental effects of UV irradiation on skin are mediated by the increased formation of free radicals and by the direct absorption of energy by cell biomolecules. The free radicals may directly alter the structure of DNA (Ouhtit and Ananthaswamy 2001; Laga and Murphy 2009), proteins (Laga and Murphy 2009) and lipids (e.g. lipid peroxidation) (Sorg et al. 2007) and modulate the gene expression of a wide range of proteins through the modulation of various signal transduction pathways. These events are connected with changes in the composition and turnover of the extracellular matrix (ECM), which characterize skin aging.

Reduction in the main components of the ECM, particularly collagen, due to natural skin chronoaging and photoaging may arise from their reduced synthesis and increased degradation due to an elevation of matrix metalloprotease (MMP) expression (Chung et al. 2001; Fisher et al. 2009). MMPs are a family of proteolytic enzymes that specifically degrade collagen, elastin and other proteins. MMP gene expression can be triggered by increased oxidative stress (Kim et al. 2004; Wenk et al. 2004). MMP-1 (collagenase-1) preferentially degrades fibrillar collagens, which maintain the strength of connective tissue, whereas MMP-3 (stromelysin-1) degrades a broad array of proteins. UV irradiation induces the expressions of interstitial MMP-1 and - 3 in normal human dermal fibroblasts (NHDF) in vitro and human epidermis in vivo (Wenk et al. 2004). In the naturally aged skin of old subjects in comparison with young skin, the level of MMP-1 and the activities of MMP-2 and MMP-9 tend to be higher (Fisher et al. 2009). MMP inhibitors (TIMP1, TIMP-2) have been shown to be highly up-regulated in fibrosis but not to be elevated in aged human skin in vivo (Fisher et al. 2009). Hyaluronic acid (HA) is another key component of the dermal ECM. Hyaluronan synthases 1, 2, and 3 are responsible for the cell and tissue specific regulated synthesis of HA (Girish et al. 2009). Catabolism of HA is achieved through the family of hyaluronidases (Hyal) or through nonspecific degradation by reactive oxygen species. In particular, Hyal 2 is suggested to be responsible for the degradation of HA in connective tissue (Jenkins et al. 2004). UV-induced degradation of HA by Hyals results in a loss of HA from the skin (Dai et al. 2007).

In vitro, stress-induced premature senescence of NHDF is not induced only by the exposure of cells to UV-irradiation, but can be evoked by serum-deprivation, which results in increased production of reactive oxygen species, or by direct exposure to a variety of oxidative stress and DNA damaging agents (Debacq-Chainiaux et al. 2005; Lee et al. 2006). The phenomenon of stress-induced premature senescence of
NHDF is associated with the induction of $\beta$-galactosidase activity and the expressions of various proteins, including the expression of connective tissue growth factor (CTGF), the CTGF-driven expression of fibronectin, and the expression of proteins involved in the regulation of cell arrest (Song et al. 2007; Yu et al. 2009). Fibronectin, an abundant component of the ECM, is important in the control of the morphology, adhesion and migration of fibroblasts. Previously, it was shown that senescent fibroblasts, compared to young, proliferation-competent fibroblasts, contain a high steady-state level of fibronectin gene expression (Kumazaki and Mitsui 1995). Interestingly, increased levels of fibronectin have also been detected in plasma as well as intracellularly in vascular endothelial cells and skin fibroblasts from aged individuals (Ksiazek et al. 2009).

One approach to protect skin from harmful effects of UV irradiation is to use active photoprotectives. Among the highly efficient ones are natural herbal extracts that comprise polyphenolic compounds. Natural plant extracts are now gaining more pharmacological attention, as many previously unexplored plant species appear to demonstrate a wide range of activities, such as anti-cancer activities (Vitalone et al. 2003a, 2003b, 2006; Scheck et al. 2006), DNA protective and antimutagenic activities (Miadokova et al. 2010; Kopaskova et al. 2011), anti-inflammatory activities (Talhouk et al. 2007), and anti-aging activities (Kim et al. 2004). Among them are extracts from the aerial parts of Epilobium angustifolium (EA) (Oenotheraceae). These extracts were reported to possess significant antioxidant activity due to the high content of polyphenolic substances such as ellagitannins, gallotannins, phenolic acids, and flavonol glycosides (Bazylko et al. 2007). EA is used in folk medicine for prostate and gastrointestinal disorders; to treat mucous membrane lesions, such as mouth ulcers; and to improve the healing of wounds, skin sores and swelling (Kiss et al. 2011).

Thus, the goal of the present study was to elucidate the anti-aging and anti-photoaging features of $E A$ extract both in-vitro and in-vivo. We focused on ECM metabolism and the senescent phenotype of fibroblasts, and aimed to explore the mechanism of $E A$ extract action. To confirm in vitro data, the photoprotective effect of $E A$ extract was tested on human volunteers after UV exposure. Interestingly, EA extract exhibited a significant photoprotective effect.

\section{Materials and Methods}

\section{EA extract preparation}

All chemicals were purchased from Sigma-Aldrich (St Louis, Mo, USA), if not indicated otherwise. Dried aerial parts of $E A$ were obtained from the commercial supplier Byliny Mikeš s.r.o. (Číčenice, Czech Republic) with the 
batch number 102011. Plant samples were botanically authenticated by using microscopic methods at the Department of Pharmacognosy, Charles University, Czech Republic. One kilogram of dried aerial parts of $E A$ was extracted in $75 \%$ (v/v) isopropylalcohol (5 l) by maceration over a period of 12 days at room temperature. The obtained extract was filtered and the solvent was then removed under reduced pressure by a rotary evaporator at $38^{\circ} \mathrm{C}$. The extraction yield was $10 \% \mathrm{w} / \mathrm{w}$ on a dry weight basis. The resulting dried extract was re-dissolved in a mixture of $0.5 \mathrm{~kg}$ of 1.3 -butanediol and $0.125 \mathrm{~kg}$ water, immediately filtered and stored in sterile conditions. The final EA extract (200 $\mathrm{mg} / \mathrm{ml})$ in 80\% 1.3-butanediol was evaluated for its biological activities.

\section{HPLC-DAD-MS analysis}

The EA extract was chemically analyzed on an Acquity system (Waters, USA) equipped with a vacuum degasser, a binary UPLC pump, a thermostatted autosampler, a thermostatted column compartment, and a Waters UPLC PDA detector. The HPLC-PDA system was coupled directly to a Waters Synapt HDMS mass spectrometer. Elution was performed on a $5 \mu \mathrm{m}$ Luna C18(2) column $(250 \mathrm{~mm} \times$ $4.6 \mathrm{~mm}$; ambient temperature, flow-rate: $1 \mathrm{ml} / \mathrm{min}$ ). Briefly, two mobile phases were employed for elution: (A) $0.1 \%$ formic acid and (B) methanol. Separation was achieved with a gradient elution as follows: $0-5 \mathrm{~min}, 0 \% \mathrm{~B} ; 25 \mathrm{~min}, 20 \%$ B; $30 \mathrm{~min}, 20 \% \mathrm{~B} ; 70 \mathrm{~min}, 40 \% \mathrm{~B} ; 75 \mathrm{~min}, 40 \% \mathrm{~B}$; $95 \mathrm{~min}$, $60 \% \mathrm{~B} ; 100 \mathrm{~min}, 60 \% \mathrm{~B} ; 110 \mathrm{~min}, 100 \% \mathrm{~B} ; 125 \mathrm{~min}, 100 \%$ $\mathrm{B} ; 127 \mathrm{~min}, 0 \% \mathrm{~B} ; 135 \mathrm{~min}, 0 \% \mathrm{~B}$. The injection volume was $10 \mu \mathrm{l}$. The constituents of $E A$ extract were monitored at 254 and $340 \mathrm{~nm}$. The mass spectrometry (MS) measurements were executed with electrospray ionization (ESI) in negative ion mode with the following settings: desolvation gas temperature, $350^{\circ} \mathrm{C}$; source temperature, $120^{\circ} \mathrm{C}$; cone gas flow rate, $50 \mathrm{l} / \mathrm{h}$; desolvation gas flow rate, $700 \mathrm{l} / \mathrm{h}$; and sampling cone voltage, 50 . The capillary voltage was $2.7 \mathrm{kV}$. For tandem mass spectrometry (MS/MS), a collision energy ramp ranging from 40 up to $70 \mathrm{~V}$ was applied. The full mass scan ranged between the mass/charge $(\mathrm{m} / \mathrm{z}) 50$ and $2000 \mathrm{Da}$. The components of $E A$ extract were identified on the basis of their UV and MS spectra after comparing them with literature data and authentic standards (chlorogenic and gallic acids).

\section{Total reactive antioxidant potential (TRAP)}

The method is based on peroxyl radicals produced at a constant rate by thermal decomposition of 2,2'-azobis(2-amidinopropane) dihydrochloride (ABAP), which was monitored by luminol-enhanced chemiluminescence measurement as described previously (Slavikova et al. 1998). Briefly, $110 \mu \mathrm{l}$ of $100 \mathrm{mM}$ sodium phosphate buffer, $\mathrm{pH} 7.4$, and $10 \mu \mathrm{l}$ of diluted $E A$ extract $(1.75 \mathrm{mg} / \mathrm{ml})$ or $10 \mu \mathrm{l} 200 \mu \mathrm{M}$ Trolox were pipetted into a microtiter plate. The plate was shaken and $20 \mu \mathrm{l}$ of $0.5 \mathrm{mM}$ luminol in $100 \mathrm{mM}$ borate buffer, $\mathrm{pH} 8.5$, was added into each well. After $10 \mathrm{~min}$ of incubation at $37^{\circ} \mathrm{C}$, the reaction was initiated by the addition of $60 \mu \mathrm{l}$ of $100 \mathrm{mM}$ ABAP and the chemiluminescence was recorded using an Infinite M200 luminometer (Tecan, Switzerland). The time to recover the temporarily quenched chemiluminescence at $37^{\circ} \mathrm{C}$ was measured, and TRAP $(\mu \mathrm{mol} / \mathrm{l})$ was calculated using a Trolox reference according to the following equation:

TRAP $=2.0 . \mathrm{n}_{\text {Trolox }} / \mathrm{V}_{\text {sample }} \cdot \mathrm{T}_{\text {sample }} / \mathrm{T}_{\text {Trolox }}$ where 2.0 is the stoichiometric factor of Trolox (the number of peroxyl radicals trapped per one molecule of Trolox), $\mathrm{n}_{\text {Trolox }}$ is the molar amount of Trolox added into reference wells expressed in $\mu \mathrm{mol}, \mathrm{V}_{\text {sample }}$ is the volume of the sample added to the reaction expressed in litres, $\mathrm{T}_{\text {sample }}$ is the induction time observed for the sample, $\mathrm{T}_{\text {Trolox }}$ is the induction time observed for the reference compound (Trolox).

\section{NHDF cultivation and experimental models}

NHDF were obtained after the removal of skin fragments during plastic surgeries (mainly modification of the auricle) on young donors (aged from 8 to 35 years) without any skin pathologies and with equal gender distribution. NHDF were cultivated as described previously (Faury et al. 2008). Cells were grown in Dulbecco's Modified Eagle Medium (PanBiotech, Germany) containing 10\% fetal bovine serum (FBS, PanBiotech, Germany), amphotericin B, penicillin, and streptomycin at $37^{\circ} \mathrm{C}$ in a $7.5 \% \mathrm{CO}_{2}$ atmosphere, and the culture medium was changed every 2 days. After one passage, cells were seeded at a density of $2 \times 10^{4}$ per $\mathrm{cm}^{2}$ in six well plates and used for experiments. The effects of $E A$ extract on the response of senescent NHDF induced by both chronic and acute stress were determined.

To induce chronic stress in NHDF, often referred to as in vitro simulated senescence of NHDF, two approaches were employed. As a first approach, the NHDF cells were cultured in deprived conditions for $72 \mathrm{~h}$, during which the treated cells were incubated with $E A$ extract $(10 \mu \mathrm{g} / \mathrm{ml})$. Then, the cells and media were harvested for analysis. As a second approach, the NHDF cells were repeatedly irradiated by $2 \mathrm{~mJ} / \mathrm{cm}^{2} \mathrm{UV}$ every $24 \mathrm{~h}$ for 72 or $120 \mathrm{~h}$ in total using a xenon arcsolar UV-simulator A (Oriel Instruments, Stradford, CT, USA) equipped with a combination of UG5 and WG280 Schott filters and a COLIPA compliant UV-spectrum in the range from $280 \mathrm{~nm}$ to approximately $410 \mathrm{~nm}$. During the irradiation process, the cell culture medium was replaced with Hank's balanced Salt Solution, pH 7.4 (PanBiotech, Aidenbach, Germany). Cells and media were harvested for analysis after 72 and 120 hours of repeated UV irradiation. 
To induce acute stress in NHDF, more intensive UV-irradiation $\left(7 \mathrm{~mJ} / \mathrm{cm}^{2}\right)$ was employed. Given that under these conditions SIRT-1 expression was found to be deregulated, this model was used for determining the effect of $E A$ extract on SIRT-1 expression. Cells were harvested $4 \mathrm{~h}$ after UV irradiation.

In general, the time periods for cell treatment were selected on the basis of our previously published data (Ruszova et al. 2008) and preliminary results, which identified the maximal response of cells to a selected compound or stressor (data not shown).

The concentrations for in vitro experiments were selected on the basis of the effects on cell proliferation and cell viability. EA extract concentrations up to $66 \mu \mathrm{g} / \mathrm{ml}$ did not reveal any significant inhibition of cell proliferation or any effects on cell viability (data not shown). In contrast, $660 \mu \mathrm{g} / \mathrm{ml} E A$ extract induced significant inhibition of cell proliferation, without having any effect on cell viability (data not shown). The solvent 1.3-butanediol up to a final concentration of $0.26 \%$ did not induce any effect on cell proliferation or cell viability (data not shown). Thus, for in all in vitro experiments, the final tested concentration of $E A$ extract was selected $10 \mu \mathrm{g} / \mathrm{ml}$ and the equivalent final concentration of the 1.3 -butanediol was $0.004 \%$.

\section{Cell viability}

Cell viability was determined on the basis of the detection of the total cellular mass of adherent live cells that was measured by protein concentration in whole cell lysates. This estimation correlates with other types of determination of cell viability (metabolism-based assays) as we previously reported (Vistejnova et al. 2009). The cells were washed in cold PBS, lysed in sodium dodecyl sulfate buffer $(50 \mathrm{mM}$ Tris- $\mathrm{HCl}, \mathrm{pH}$ $7.4,100 \mathrm{mM} \mathrm{NaCl}, 10 \%$ glycerol, $1 \%$ sodium dodecyl sulfate, $1 \mathrm{mM}$ ethylenediaminetetraacetic acid, and $10^{-3} \mathrm{~mol} / \mathrm{l}$ phenylmethanesulfonyl fluoride), and frozen at $-80^{\circ} \mathrm{C}$. The samples were boiled and sonicated, and the concentration of proteins was determined using protein assay (Bio-rad, RCDC protein assay, USA) (Krejcova et al. 2009).

\section{Analysis of gene expressions of CTGF, fibronectin, Hyal-2 and SIRT-1}

RNA extraction was performed as described previously (Ruszova et al. 2008). The RNA yield and the ratio of absorbance at $260 \mathrm{~nm}$ to absorbance at $280 \mathrm{~nm}\left(\mathrm{~A}_{260} / \mathrm{A}_{280}\right.$ ratio) were measured using a NanoDrop ND-1000 Spectrophotometer (NanoDrop Technologies, Switzerland). First-strand cDNA was synthesised using the High Capacity cDNA Reverse Transcription Kit (Applied Biosystems, Switzerland) and random primers according to the manufacturer's instructions. cDNA equivalent to 5-40 ng of total RNA was used for QRT-PCR, using pre-validated TaqMan gene expression assays (Applied Biosystems, USA) for CTGF (no. Hs00170014_m1), fibronectin 1 (no. Hs01549976_m1), Hyal-2 (no. Hs01117343_g1), SIRT-1 (no. Hs01009006_m1) and housekeeping gene HPRT1 (no. Hs99999909_m1). Data are expressed as fold-changes relative to untreated fibroblasts calculated by REST software -384 v.1 (Pfaffl et al. 2004).

\section{Multiplex MMP and TIMP assays}

Fluorokine Multiplex MMP assay (MMP-1, MMP-2, MMP-3, MMP-9) (LMP 000, LMP901, LMP902, LMP513, LMP911, R\&D Systems, Abingdon, UK) and Fluorokine TIMP assay (TIMP-1, 2, 3, 4) (LKT 004, R\&D Systems, Abingdon, UK) were performed according to the manufacturer's instructions.

\section{Test of primary irritancy in human subjects}

To determine the maximum non-irritating dose of $E A$ extract, a test of primary irritancy (patch test) was conducted with the prior approval of the Institutional Review Board at Contipro Biotech (protocol number 01/2010) and in agreement with the protocols of the Declaration of Helsinki. The patch test involved the application of EA extract under adhesive tape, which was left in place for 4 hours (OECD 404 Guideline for the testing of chemicals). All the volunteers gave their written informed consent. Thirty-three human volunteers were employed for this test and a one-point application of $35 \mu \mathrm{l}$ of $E A$ extract ( $5 \%$ solution e.g. $50 \mathrm{mg} / \mathrm{ml}$ ) in occlusion (IQ Ultra Chamber, Chemotechnique Diagnostics, Sweden) was used, as well as one-point applications of $35 \mu \mathrm{l}$ of the solvent (1,3-butanediol, $4 \%$ in PBS) and $35 \mu \mathrm{l}$ of PBS alone.

\section{Skin exposure to UV irradiation}

Eight healthy Caucasian volunteers aged 40-50 years without any form of skin hypersensitivity or any reported pathologies (Fitzpatrick types II and III) were included in the evaluation. The study was approved by the local ethics committee and each person signed an informed consent form. A xenon arc solar UV-simulator A (Oriel Instruments, USA) equipped with a dichroic mirror and with a combination of UG5 and WG280 Schott filters, producing a UV spectrum range from $280 \mathrm{~nm}$ to approximately $410 \mathrm{~nm}$ (the COLIPA compliant UV-spectrum), was used for the irradiation of the skin sites. The minimum UV minimal erythema dose (MED) for all volunteers was determined 2-4 days before testing individually. The MED was defined as the dose that induced a barely perceptible erythema at 28-32 h after UV irradiation (Ley 1985), which 
was judged by two observers. Skin redness before irradiation, and both 24 hours and 48 hours after irradiation was measured using a Spectrocam 75 RE (Spectrostar, USA) reflectance spectrophotometer.

To test the EA photoprotective effect in vivo, carbomer $(0.5 \%)$ gel with $3 \%$ of $E A$ extract and a control gel with $2.4 \%$ of 1,3-butanediol corresponding to $3 \%$ of extraction solvent content were used. Pre-defined skin sites $3 \times 1.2 \mathrm{~cm}$, marked on the forearm of each human volunteer, were pre-treated with both preparations 3 times a day for 14 consecutive days. After the pre-treatment period, active- and control-treated skin sites, as well as untreated skin sites were cleansed gently with pure water and allowed to dry. The initial $\mathrm{a}^{*}$ values and erythema indexes for each skin site were determined by reflectance values measurement within the range $380-780 \mathrm{~nm}$. The $\mathrm{a}^{*}$ values of $L^{\star} a^{\star} b^{\star}$ color space were computed by Spectrocam software; the erythema indexes were calculated according to Wagner et al. (Wagner et al. 2002). Then, erythemal doses of 1.25 MED of UV radiation were applied once to each treated and untreated skin site. The treatments with $E A$ extract and control gels continued three times during the following 24 hours. Finally, the cleaned skin sites were photographed (Coolpix 4500, Nikon, Japan) 24 hours and 48 hours after irradiation and the redness was determined spectrophotometrically. For each site, four determinations were performed and the mean value was calculated. Skin redness changes were expressed as the differences between the initial and final erythema indexes values measured for the test, control (solvent), and adjacent untreated reference skin sites.

\section{Statistical analysis}

Results are presented as the means \pm SD derived from at least three independent experiments. Analysis was performed using Statistica for Windows v. 5.0 (StatSoft, Inc., Tulsa, OK, USA).

\section{Results}

\section{HPLC-UV-MS analysis of EA extract}

The chemical profile of EA extract was determined by HPLC-UV-MS analysis. The peak identities in the chromatogram were determined on the basis of their UV and MS spectra after comparison with data reported in literature

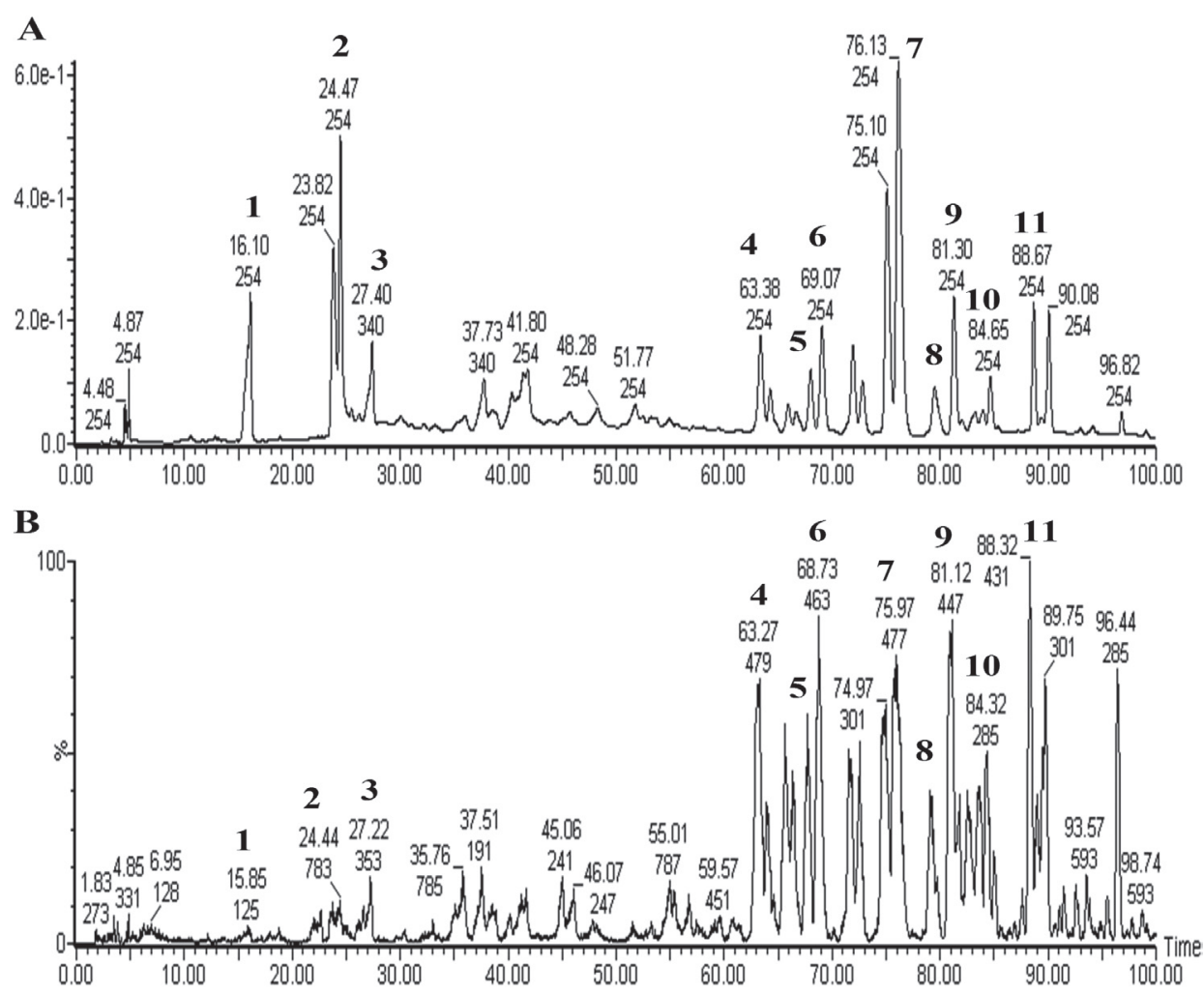

Figure 1. HPLC-UV (A) and HPLC-MS (B) chromatograms of EA extract. Peaks: (1) gallic acid; (2) oenothein B; (3) chlorogenic acid; (4) myricetin-3-O-hexoside; (5) myricetin-3-O-pentoside; (6) myricetin-3-O-rhamnoside; (7) quercetin-7-O-glucuronide; (8) quercetin-3-Opentoside; (9) kaempferol-3-O-hexoside; (10) kaempferol-7-O-glucuronide; and (11) kaempferol-3-O-rhamnoside. 
(Fig. 1). The UV spectra and retention times of peaks 1 (UV $\lambda_{\max }$ at 213 and $278 \mathrm{~nm}$ ) and 3 (UV $\lambda_{\max }$ at 215 and $327 \mathrm{~nm}$ ) were consistent with those from authentic standards of gallic and chlorogenic acids, respectively, as well as with literature data. The UV spectra of peak 2 (UV $\lambda_{\max }$ at 213 and $264 \mathrm{~nm}$ ) was consistent with that reported in literature for ellagitannins (Karonen et al. 2010). The assignment of flavonoids to peaks 4-12 was unambiguous, since these exhibit characteristic UV spectra. Accurate mass and MS/MS fragmentation experiments in the negative ion mode were also conducted. The MS data are summarized in Table 1. For instance, a loss of $\mathrm{CO}_{2}$ was observed for peak 1 giving the $[\mathrm{M}-\mathrm{H}-44]^{-}$as a characteristic ion of gallic acid. Peak 3 showed the deprotonated molecule $[\mathrm{M}-\mathrm{H}]^{-}(\mathrm{m} / \mathrm{z} 353)$ and the ion corresponding to the deprotonated quinic acid $(m / z 191)$, which is distinctive for chlorogenic acid (Sanchez-Rabaneda et al. 2003). Peak 2 revealed two abundant ions at $\mathrm{m} / \mathrm{z} 783$ and 1567, which are in agreement with those observed in the MS spectrum of oenothein B (Granica et al. 2012). The molecular ion at $\mathrm{m} / \mathrm{z}$ 783 is assumed to be a doubly charged $\left([\mathrm{M}-\mathrm{H}]^{2-}\right)$, while the molecular ion at $m / z 1567$ is assumed to be a charged molecular ion form $\left([\mathrm{M}-\mathrm{H}]^{-}\right)$of oenothein $\mathrm{B}$, as mentioned earlier (Hevesi Toth et al. 2009). The molecular ion and MS/MS fragmentation profiles of peaks 4-12 were consistent with those of flavonols identified in Epilobium species (Davis and Brodbelt 2008). The MS spectra showed the deprotonated molecule $[\mathrm{M}-\mathrm{H}]^{-}$and the ion corresponding to cleavage of the sugar unit $[\mathrm{M}-\mathrm{H}-\mathrm{Gly}]^{-}$, giving two ions representative of the molecule. The fragment ions appearing at $m / z 317$ (peaks 4, 6 and 7), $m / z 285$ (peaks 11 and 12 ) and $m / z 301$ (peaks $5,8,9$ and 10) are characteristic of myricetin, kaempferol and quercetin aglycones, respectively
(Lin and Harnly 2007). The mass difference between the molecular ion $[\mathrm{M}-\mathrm{H}]^{-}$and aglycone fragments gave useful information on the nature of the sugar moiety - a difference of $162 \mathrm{amu}$ for hexose; 146 amu for deoxyhexose, most probably rhamnose; 132 amu for pentose; and $176 \mathrm{amu}$ for glucuronic acid. The signal at $\mathrm{m} / \mathrm{z} 463$ (peak 5) was due to the loss of a galloyl moiety (-152 amu). Unlike flavonol 3-O-monoglycosides, flavonol 7-O-monoglycosides had been reported to yield abundant aglycone fragment ions $[\mathrm{M}-\mathrm{H}]^{-}$((Lu et al. 2009). Therefore, peaks 8 and 11, showing a high relative abundance (100\%) of aglycone fragment ions (Table 1), were tentatively assigned to flavonol 7-Oglycosides. EA extract showed radical-scavenger activity determined by TRAP compared to Trolox and sodium gallate as standard antioxidants (Fig. 2).

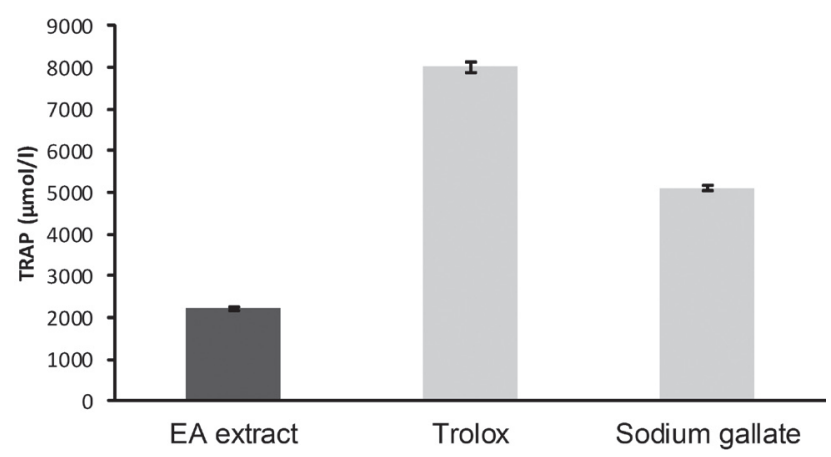

Figure 2. Antioxidant capacity of $E A$ extract determined as TRAP of ABAP monitored by luminol-enhanced CL. The value is recalculated for a final concentration of $1 \mathrm{~g} / \mathrm{l}$ of the solid EA extract. Data represent mean $\pm \operatorname{SD}(n=3)$.

Table 1. MS data of the components observed in the herbal preparation from a commercial sample of Epilobium angustifolium (EA)

\begin{tabular}{clcl}
\hline Peaks & Components & {$[\mathrm{M}-\mathrm{H}]^{-}$} & $\begin{array}{l}\mathrm{MS}^{2} \text { product ions } \\
\text { (\% relative intensity) }\end{array}$ \\
\hline 1 & Gallic acid & 169 & $125(22)$ \\
2 & Oenothein B & $1567 / 783[\mathrm{M}-2 \mathrm{H}]^{2-}$ & $765(100), 301(58)$ \\
3 & Chlorogenic acid & 353 & $191(88), 135(100)$ \\
4 & Myricetin-3-O-hexoside & 479 & $317(22), 179(5), 151(8)$ \\
5 & Quercetin-3-O-hexose-gallate & 615 & $463(10), 301(40), 151(18)$ \\
6 & Myricetin-3-O-pentoside & 449 & $317(28), 179(5), 151(9)$ \\
7 & Myricetin-3-O-rhamnoside & 463 & $317(33), 179(8), 151(9)$ \\
8 & Quercetin-7-O-glucuronide & 477 & $301(100), 179(10), 151(20)$ \\
9 & Quercetin-3-O-pentoside & 433 & $301(78), 179(8), 151(20)$ \\
10 & Quercetin-3-O-rhamnoside & 447 & $301(60), 179(5), 151(12)$ \\
11 & Kaempferol-7-O-glucuronide & 461 & $285(100), 257(6), 229(10), 151(3)$ \\
12 & Kaempferol-3-O-rhamnoside & 431 & $285(38), 257(17), 229(18), 151(4)$ \\
\hline
\end{tabular}

The MS measurements were executed with electrospray ionization (ESI) in negative ion mode and the components of $E A$ extract were identified on the basis of their molecular ions $[\mathrm{M}-\mathrm{H}]^{-}$and $\mathrm{MS}^{2}$ product ions. 
EA extract increased the cell viability of senescent NHDF induced by serum deprivation

The effect of $E A$ extract on the cell viability of senescent NHDF induced by serum deprivation was tested. Serum deprivation for 72 hours induced a significant decrease in the cell viability of NHDF (Fig. 3). EA extract $(10 \mu \mathrm{g} / \mathrm{ml})$ revealed a protective effect on the viability of senescent NHDF induced by serum deprivation (Fig. 3). However, no effect on the viability of senescent NHDF induced by UVBirradiation was observed (data not shown).

\section{EA extract diminished CTGF and fibronectin gene expres- sions in senescent NHDF}

The NHDF senescence induced by serum-deprivation was connected with the up-regulation of CTGF gene expression, a characteristic marker of senescent cells (Fig. 4A). Interestingly, treatment with $E A$ extract led to a significant reduction in CTGF gene expression levels (Fig. 4A). A down-regulating effect of $E A$ extract on fibronectin gene expression in NHDF senescent cells was also observed (Fig. 4B).

EA extract down-regulated releases of $M M P-1,-3$ and TIMP-1,-2 by repeatedly UV irradiated NHDF

To characterize the protective effects of $E A$ extract against UV-induced ECM degradation as well as anti-fibrotic and anti-scarring effects, the modulating effect of $E A$ extract on both the release of MMPs and their inhibitors TIMPs was

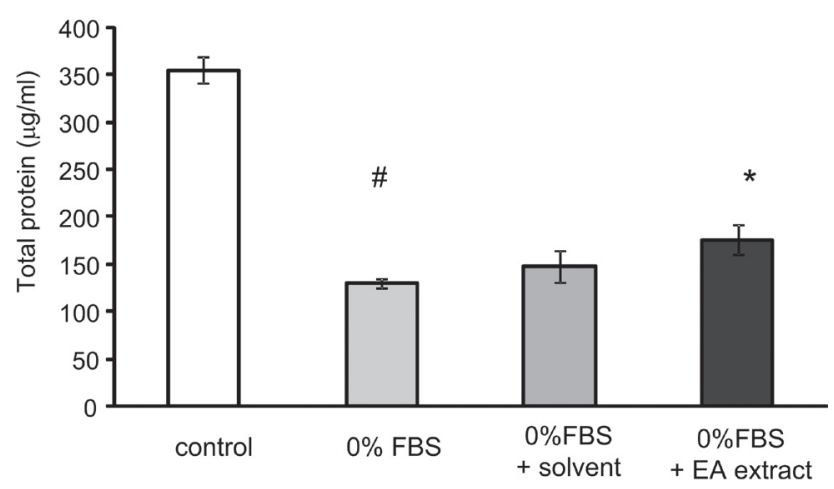

Figure 3. Effects of $E A$ extract $(10 \mu \mathrm{g} / \mathrm{ml})$ on the viability of serum-deprived NHDF after $72 \mathrm{~h}$ of cultivation. NHDF cultured in complete media with $10 \%$ FBS served as the total untreated control. Control $0.004 \%$ solvent 1.3 -butanediol was also tested. ${ }^{*}$ statistically significant differences (T-test, $p<0.05$ ) between the sample group of NHDF cultured in complete media and serum deprived group; ${ }^{*}$ differences between the sample group of $E A$-treated serum deprived NHDF and the respective serum deprived NHDF group. Data represent mean $\pm \mathrm{SD}(n=3)$. evaluated 120 hours after irradiation. EA extract $(10 \mu \mathrm{g} / \mathrm{ml})$ significantly inhibited MMP-1 production in UV-irradiated NHDF (Fig. 5A). However, no significant effect on MMP-3 was observed (Fig. 5B). UV-irradiation of NHDF induced the release of TIMP-1 (Fig. 5C), but TIMP-2 expression was unchanged (Fig. 5D). EA extract $(10 \mu \mathrm{g} / \mathrm{ml})$ significantly inhibited TIMP-1 and TIMP-2 production (Fig. 5C, D). The presence of TIMP-3 and TIMP-4 in cell culture media was not detected in any sample.

\section{EA extract diminished Hyal-2 gene expression by NHDF induced by repeated $U V$ irradiation}

To further characterize the effects of $E A$ extract on the metabolism of ECM components, the expressions of enzymes involved in HA metabolism were evaluated. Hyal-1 was not detected in any sample and hyaluronan-synthases 1 and 2 were not markedly influenced by $E A$ extract treatment (data not shown). In accordance with literature, the most signifi-

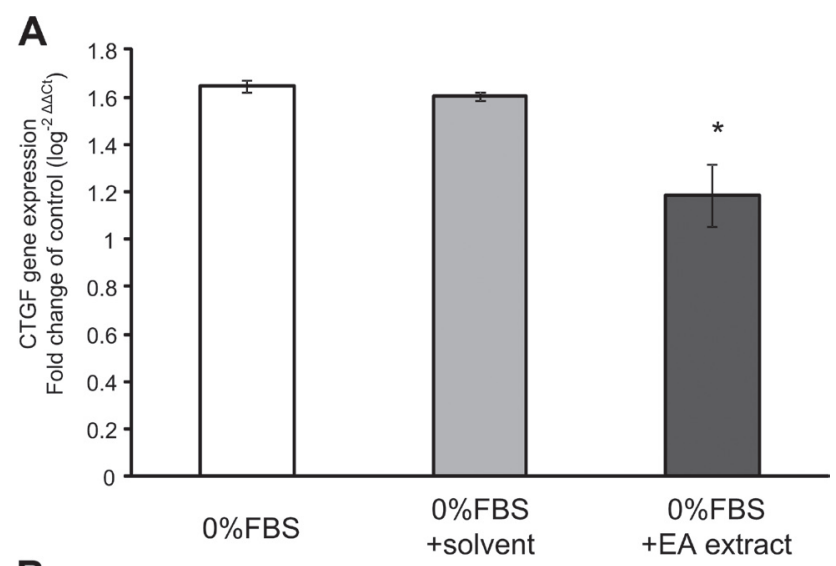

B

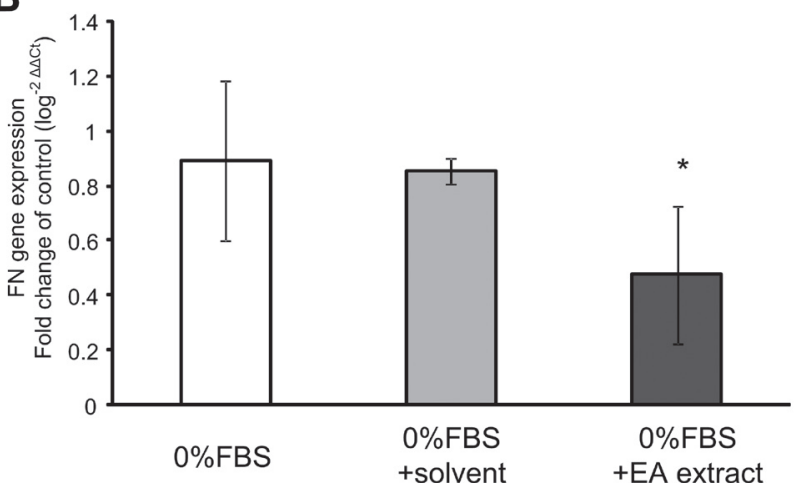

Figure 4. Effect of $E A$ extract $(10 \mu \mathrm{g} / \mathrm{ml})$ on the CTGF (A) and fibronectin (B) gene expressions in serum-deprived NHDF $72 \mathrm{~h}$ after serum deprivation. Control $0.004 \%$ solvent 1.3 -butanediol was also tested. NHDF cultured in complete media with $10 \%$ FBS served as the control. Data are expressed as $\log ^{-2 \Delta \Delta C t}$ with control equal to 0 . * statistically significant differences (T-test, $p<0.05$ ) to the control serum deprived NHDF group. Data represent mean $\pm \operatorname{SD}(n=3)$. 
cant changes were observed with Hyal-2 gene expression, which is considered to be a contributor to ECM degradation (Girish et al. 2009). The UV-irradiation of NHDF for 120 hours significantly induced Hyal-2 gene expression (Fig. 6). EA extract $(10 \mu \mathrm{g} / \mathrm{ml})$ completely inhibited Hyal2 gene expression in UV-irradiated NHDF (Fig. 6). The treatment of NHDF with solvent (1,3 butandiol, $80 \% \mathrm{w} / \mathrm{w}$ in water) alone partially contributed to Hyal-2 diminution, probably by its antioxidant nature.

\section{EA extract diminished SIRT-1 down-regulation dampened by UV-irradiation}

In order to further explore the protective mechanism of $E A$ extract on NHDF, the short term response of SIRT-1 gene expression 4 hours after UV-irradiation was monitored in the presence of stabilizing agents $\left(62.5 \mu \mathrm{M} \mathrm{NAD}^{+}\right.$, and $125 \mu \mathrm{M}$ vitamin $\mathrm{C}$ ). UV-irradiation caused down-regulation in SIRT-1 gene expression in NHDF, which was significantly reversed by $E A$ extract $(10 \mu \mathrm{g} / \mathrm{ml})$ (Fig. 7$)$. SIRT-1 was not significantly changed by $E A$ extract in non-irradiated cells (data not shown).

\section{EA extract decreased $U V$-induced erythema formation in vivo}

Assessment of the primary irritancy of all tested substances showed that neither EA extract nor the solvent irritated skin up to a final concentration of $5 \%$. The evaluation of $E A$ photoprotective effects revealed that both the repeated application of EA extract ( $3 \% \mathrm{EA}$ in carbomer gel) before single UV-exposure (1,25 MED) and three point postUV exposure treatment significantly decreased erythema indexes both 24 and 48 hours after irradiation (Fig. 8A and B). Photographs of typical results of erythema skin formation on 3 volunteers are shown in Fig. 1S in Supplementary material.

\section{Discussion}

The aim of the study was to evaluate the anti-photoaging effects of $E A$ extract. The chemical characterization of the components of $E A$ extract was consistent with previous reports showing that oenothein $\mathrm{B}$ and quercetin-7-O-glucuronide are species-specific components of $E A$ glycosides;
A

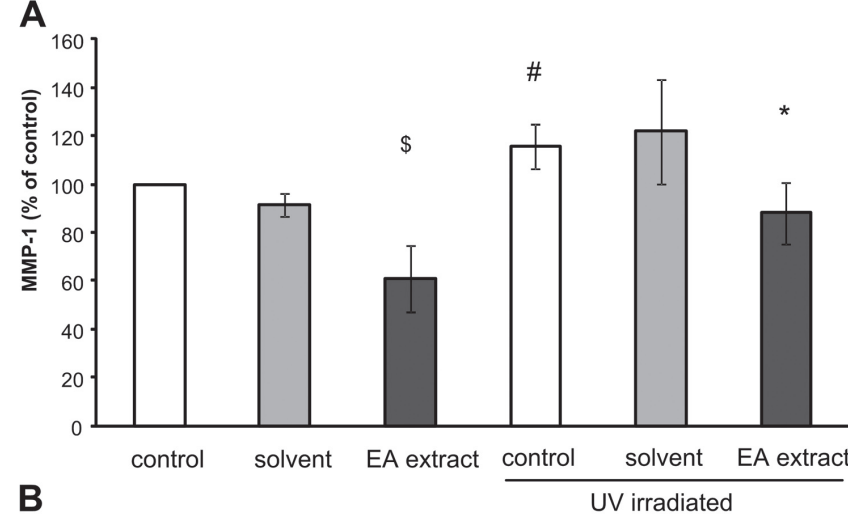

B

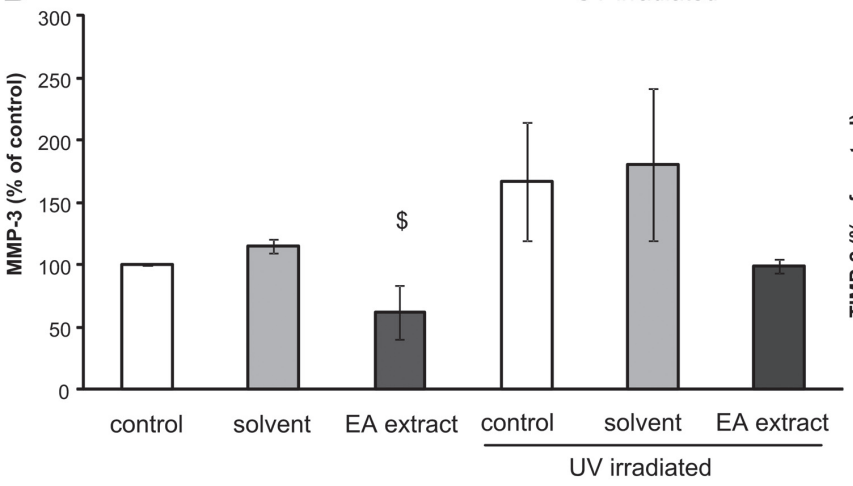

C
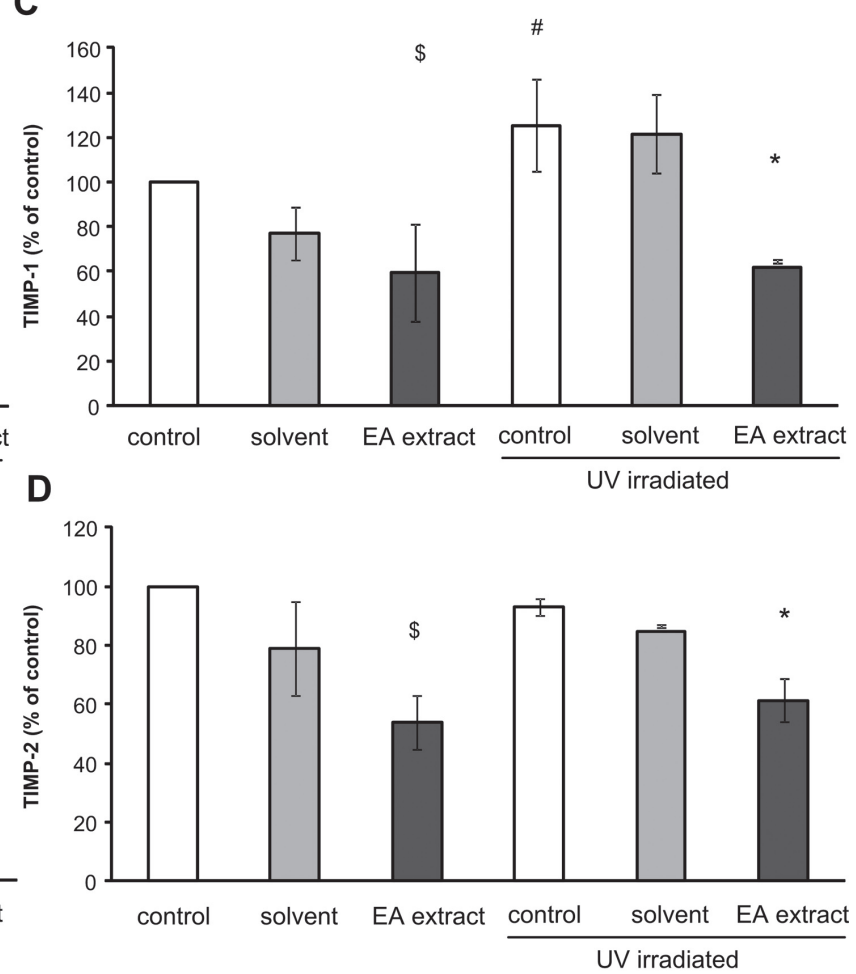

Figure 5. Effect of EA extract (10 $\mu \mathrm{g} / \mathrm{ml})$ on MMP-1 (A), MMP-3 (B), TIMP-1 (C) and TIMP-2 (D) release by repeatedly UV irradiated NHDF for 120 hours. Control $0.004 \%$ solvent 1.3-butanediol was also tested. " Statistically significant differences (T-test, $p<0.05)$ between control and UV-irradiated NHDF groups; ${ }^{\$}$ statistically significant differences (T-test, $p<0.05$ ) to the control NHDF group; * differences to the UV-irradiated NHDF group. Data represent mean $\pm \mathrm{SD}(n=3)$. 


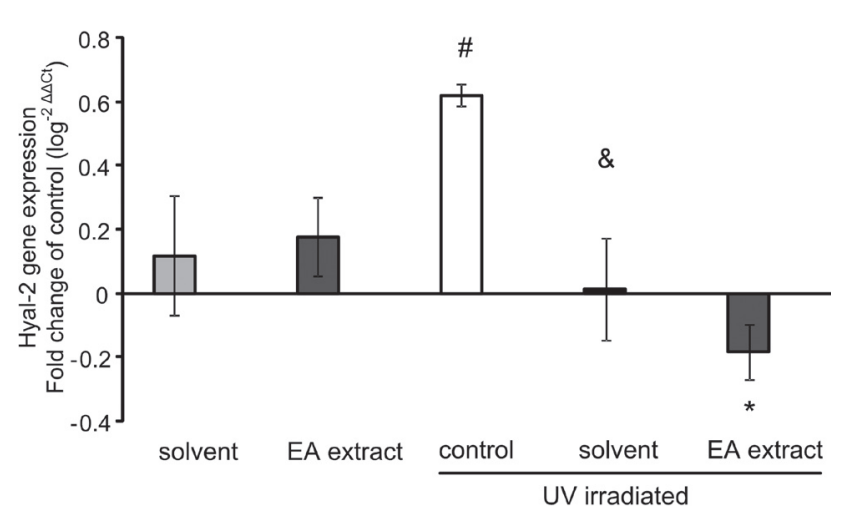

Figure 6. Effect of $E A$ extract $(10 \mu \mathrm{g} / \mathrm{ml})$ on Hyal-2 gene expression by NHDF repeatedly irradiated by UV for 120 hours. Control $0.004 \%$ solvent 1.3-butanediol was also tested. " statistically significant differences (T-test, $p<0.05$ ) between control and UV-irradiated NHDF groups and ${ }^{*}$ between EA-treated and UV-irradiated NHDF groups; \& statistically significant differences (T-test, $p<0.05$ ) to the UV-irradiated NHDF group. Data represent mean $\pm \mathrm{SD}(n=3)$.

in particular, quercetin glucuronide predominates in $E A$ (Hevesi Toth et al. 2009). In contrast, myricetin glycosides are the most prevalent flavonoids in other Epilobium species (Bazylko et al. 2007; Hevesi Toth et al. 2009). The antioxidant capacity of $E A$ extract was determined against radicals formed by the thermal decomposition of ABAP by luminol-enhanced chemiluminescence. EA extract exhibited detectable but rather low radical-scavenger activity determined by TRAP compared to Trolox and sodium gallate as standard antioxidants. In a previous study, a more potent level of antioxidant activity of $E A$ extract was determined

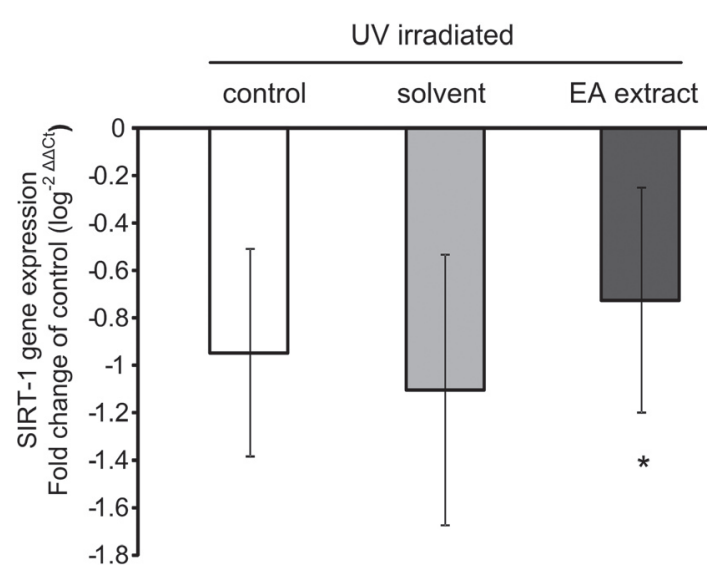

Figure 7. Effect of $E A$ extract $(10 \mu \mathrm{g} / \mathrm{ml})$ on SIRT-1 gene expression by NHDF $4 \mathrm{~h}$ after single dose UV irradiation. Control $0.004 \%$ solvent 1.3 -butanediol was also tested. ${ }^{*}$ Statistically significant differences (T-test, $p<0.05$ ) to the UV-irradiated NHDF group. Data represent mean $\pm \mathrm{SD}(n=3)$. by a spectrophotometric method, using 2,2 azinobis-(3ethylbenzthiazoline-6-sulfonic acid (Hevesi Toth et al. 2009). In that study $E A$ extracts showed high radical-scavenger activity, comparable to that of the well-known antioxidants Trolox and ascorbic acid.

Stress-induced premature senescence provoked by different external stimuli and the withdrawal of survival factors is characterized by an increase in CTGF and fibronectin expressions (Debacq-Chainiaux et al. 2005; Lee et al. 2006; Song et al. 2007; Yu et al. 2009). In the current investigation, the enhanced gene expressions of CTGF and CTGF-driven fibronectin were found 72 hours after serum deprivation. Interestingly, EA extract significantly decreased the expressions of these genes. As reported earlier, the gene expressions of CTGF and CTGF-driven fibronectin are triggered by an increase in free radical formation (Frippiat et al. 2001). Oenothein B has been found to significantly contribute to the remarkable free radical scavenging activity of $E A$ extracts (Kiss et al. 2011). It is conceivable that oenothein B could be involved in the down-regulating effect of $E A$ extract on CTGF-driven fibronectin gene expressions via free radical scavenging mechanisms.

By employing chronically irradiated NHDF, the effects of EA extract on the degradation of ECM components by MMPs were investigated. Increases in the expressions of MMP- 1 and MMP-3 as a result of repeated UV irradiation were efficiently suppressed by EA extract treatment. Other authors have shown oenothein B to inhibit MMP and to possess anti-inflammatory activity (Kiss et al. 2004). There is also evidence for the direct inhibition of MMP-2 and -9 activities by flavonoids in non-glycosylated form (Ende and Gebhardt 2004). Neither an inhibitory effect on MMP expressions nor the inhibition of their activity was observed with myricitrin (myricetin-3-O-rhamnoside) or quercitrin (quercetin-3-O-rhamnoside)-treated cells (Lin et al. 2008). Thus, another mechanism could be proposed than that in which quercetin glycosides, as metabolites of quercetin, can contribute to a decrease in MMP activity.

In addition, $E A$ extract down-regulated the protein expression of TIMP-1, which was significantly increased in chronically irradiated NHDF. In contrast, TIMP-2 release hardly changed after UV-exposure, but was also down-regulated by $E A$ extract. Interestingly, different authors provide evidence that the ethanolic extract of red wine composed primarily of gallic acid, as well as the ethanolic extract of Fraxinus rhynchophylla, suppress TIMP-1 and -2 expressions in a similar manner (Neaud and Rosenbaum 2008, Peng et al. 2010).

Hyaluronan is another major ECM component in skin. We demonstrated that the Hyal-2 gene expression responsible for HA degradation was significantly higher in irradiated NHDF. Consistently, others have 
also described the increased Hyal-2 expression in NHDF exposed to non-cytotoxic doses of UVB (Averbeck et al. 2007). In the present study, EA extract decreased Hyal-2 gene expression.

Polyphenols from plant extracts had been previously identified as potent activators of sirtuins (Quideau 2004). Thus, further experiments were carried out to investigate whether EA extract could influence levels of sirtuins in UV-exposed cells using short-term UVB-exposure. The mammalian nuclear sirtuin SIRT-1 is the most extensively studied; it acts as a guardian against cellular oxidative stress and DNA damage and provides stress resistance (Haigis and Guarente 2006). EA extract diminished the UV-mediated
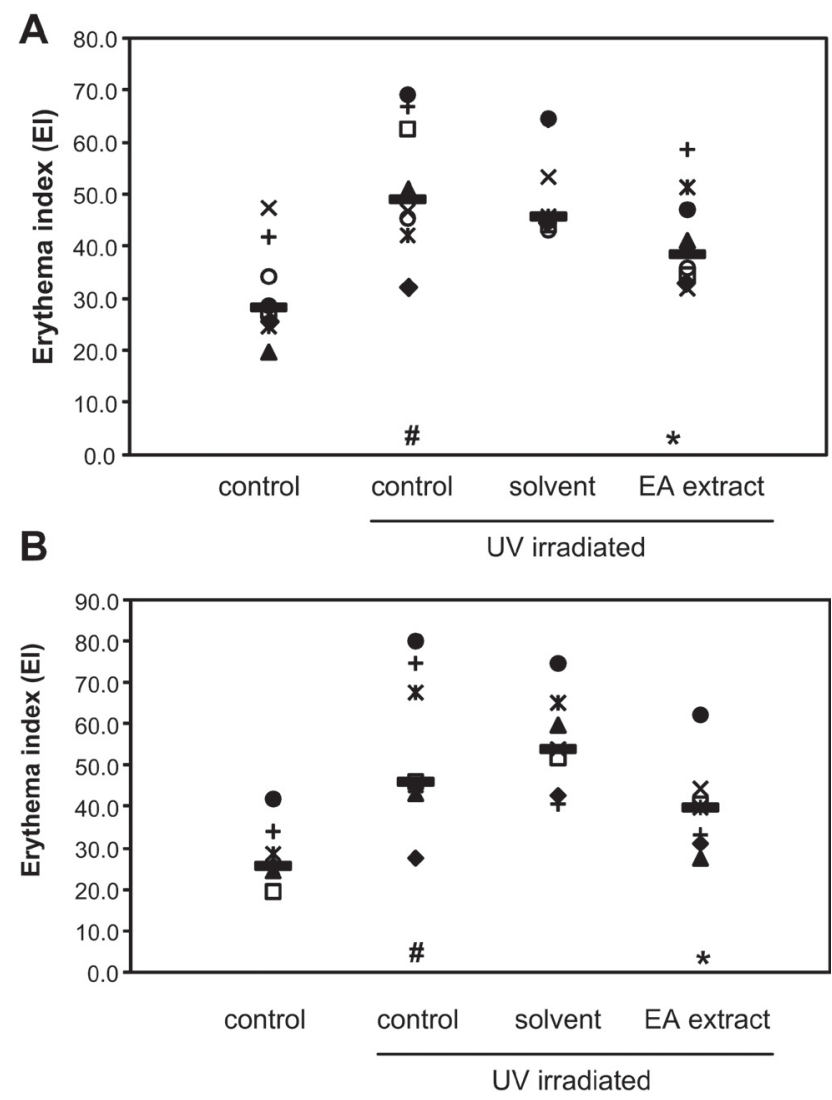

Figure 8. The application of $E A$ extract (3\% equal to $30 \mathrm{mg} / \mathrm{ml} E A$ extract) on skin visibly decreased UV-induced erythema in seven out of eight volunteers. The photoprotective effects of $E A$ extract were quantified by the evaluation of erythema indexes 24 (A) and 48 (B) hours after skin exposure to UV (1.25 MED determined for each participant). The control included solvent (2.4\% 1.3-butanediol). ${ }^{\#}$ statistically significant (Friedman ANOVA and confirmed by the Wilcoxon pair test, $p<0.05$ ) differences between control sites and UV-irradiated sites and ${ }^{\star}$ between UV-irradiated sites and $E A$-treated sites. Data are presented as median values (bold line) and particular values for each individual presented by a specific symbol $(n=8)$. down-regulation of SIRT-1 gene expression. It is noteworthy to mention that quercetin-3-O-glucuronide and gallic acid, two major $E A$ extract constituents, were shown to be SIRT-1 activators (de Boer et al. 2006). Thus, we can speculate that the final effects of the extract on SIRT-1 modulation can be potentiated by individual components of $E A$ extract.

In addition, quercetin-3-O-glucuronide was proven to inhibit the receptor activator of NF- $\mathrm{BB}$ ligand (Tsuji et al. 2009). Interestingly, the recent study of Notas and co-workers showed the quercetin-mediated induction of a high number of transcripts that are related to cell cycle, adhesion, xenobiotic metabolism, immune-related factors, and transcription together with the modification of the transcription and/or activity of numerous transcription factors (Notas et al. 2012). It can clearly be suggested that quercetin and its metabolites may exert more than just antioxidant effects on epithelial cells by regulating mechanisms related to gene transcription.

The next step was to evaluate the effects of EA on UVinduced erythema in vivo on the skin of healthy human volunteers. The application of EA extract significantly prevented UV-induced erythema formation as determined by comparison of the erythema indexes of $E A$-treated and non- $E A$-treated skin sites.

The lack of commercially available purified forms of the compounds that were identified as the key components of $E A$ extract prevented us from confirming the observed biological effects for each compound separately. However, analysis of the various results of different authors clearly indicates that observed biological effects in vitro and in vivo are mediated by specific components of $E A$ extract.

In conclusion, $E A$ extract seems to be a promising photoprotective agent. This herbal preparation can protect dermal cells and ECM components from UV-induced premature degradation, and its biological activity is augmented by several different mechanisms. EA extract, as a free radical scavenger, could prevent UV-induced dermal damage by inhibiting the induction of MMPs. The concomitant reduction in CTGF, fibronectin, and TIMPs expressions by EA extract suggests that this herbal preparation also has an anti-fibrotic/anti-scarring potential. Moreover, we propose that $E A$ extract could slow down HA degradation, which would contribute to maintenance of the quality of HA in the human dermis. The proposed protective mechanisms could also include the ability of EA to modulate SIRT-1. Importantly, the photoprotective properties of $E A$ extract were demonstrated in vivo.

Acknowledgements. The authors wish to thank Jana Stejskalova for general technical assistance. Lukas Kubala was supported by the European Regional Development Fund - Project FNUSA-ICRC (No. CZ.1.05/1.1.00/02.0123). 
Conflict of interest: V.V. has a financial interest in the company CPN, Dolni Dobrouc, the commercial producer of EA extract. E. R., J. C., S. P., I. M., M. M., M. H. are employees of CPN, Dolni Dobrouc.

\section{References}

Averbeck M., Gebhardt C. A., Voigt S., Beilharz S., Anderegg U., Termeer C. C., Sleeman J.P., Simon J.C. (2007): Differential regulation of hyaluronan metabolism in the epidermal and dermal compartments of human skin by UVB irradiation. J. Invest. Dermatol. 127, 687-697 http://dx.doi.org/10.1038/sj.jid.5700614

Bazylko A., Kiss A. K., Kowalski J. (2007): High-performance thin-layer chromatography method for quantitative determination of oenothein B and quercetin glucuronide in aqueous extract of Epilobii angustifolii herba. J. Chromatogr. A 1173, $146-150$ http://dx.doi.org/10.1016/j.chroma.2007.10.019

Chung J. H., Seo J. Y., Choi H. R., Lee M. K., Youn C. S., Rhie G., Cho K. H., Kim K. H., Park K. C., Eun H. C. (2001): Modulation of skin collagen metabolism in aged and photoaged human skin in vivo. J. Invest. Dermatol. 117, 1218-1224 http://dx.doi.org/10.1046/j.0022-202x.2001.01544.x

Dai G., Freudenberger T., Zipper P., Melchior A., Grether-Beck S., Rabausch B., de Groot J., Twarock S., Hanenberg H., Homey B., Krutmann J., Reifenberger J., Fischer J. W. (2007): Chronic ultraviolet B irradiation causes loss of hyaluronic acid from mouse dermis because of down-regulation of hyaluronic acid synthases. Am. J. Pathol. 171, 1451-1461 http://dx.doi.org/10.2353/ajpath.2007.070136

Davis B. D., Brodbelt J. S. (2008): An investigation of the homolytic saccharide cleavage of deprotonated flavonol 3-O-glycosides in a quadrupole ion trap mass spectrometer. J. Mass. Spectrom. 43, 1045-1052 http://dx.doi.org/10.1002/jms.1381

de Boer V. C., de Goffau M. C., Arts I. C., Hollman P. C., Keijer J. (2006): SIRT1 stimulation by polyphenols is affected by their stability and metabolism. Mech. Ageing Dev. 127, 618-627 http://dx.doi.org/10.1016/j.mad.2006.02.007

Debacq-Chainiaux F., Borlon C., Pascal T., Royer V., Eliaers F., Ninane N., Carrard G., Friguet B., de Longueville F., Boffe S., Remacle J., Toussaint O. (2005): Repeated exposure of human skin fibroblasts to UVB at subcytotoxic level triggers premature senescence through the TGF-betal signaling pathway. J. Cell Sci. 118, 743-758 http://dx.doi.org/10.1242/jcs.01651

Ende C., Gebhardt R. (2004): Inhibition of matrix metalloproteinase- 2 and -9 activities by selected flavonoids. Planta Med. 70, 1006-1008 http://dx.doi.org/10.1055/s-2004-832630

Faury G., Ruszova E., Molinari J., Mariko B., Raveaud S., Velebny V., Robert L., (2008): The alpha-L-Rhamnose recognizing lectin site of human dermal fibroblasts functions as a signal transducer: modulation of $\mathrm{Ca} 2+$ fluxes and gene expression. Biochim. Biophys. Acta 1780, 1388-1394 http://dx.doi.org/10.1016/j.bbagen.2008.07.008
Fisher G. J., Quan T., Purohit T., Shao Y., Cho M. K., He T., Varani J., Kang S., Voorhees J. J. (2009): Collagen fragmentation promotes oxidative stress and elevates matrix metalloproteinase- 1 in fibroblasts in aged human skin. Am. J. Pathol. 174, 101-114 http://dx.doi.org/10.2353/ajpath.2009.080599

Frippiat C., Chen Q. M., Zdanov S., Magalhaes J. P., Remacle J., Toussaint O. (2001): Subcytotoxic $\mathrm{H} 2 \mathrm{O} 2$ stress triggers a release of transforming growth factor-beta $\mathbf{1}$, which induces biomarkers of cellular senescence of human diploid fibroblasts. J. Biol. Chem. 276, 2531-2537 http://dx.doi.org/10.1074/jbc.M006809200

Girish K. S., Kemparaju K., Nagaraju S., Vishwanath B. S. (2009): Hyaluronidase inhibitors: a biological and therapeutic perspective. Curr. Med. Chem. 16, 2261-2288 http://dx.doi.org/10.2174/092986709788453078

Granica S., Bazylko A., Kiss A. K. (2012): Determination of macrocyclic ellagitannin oenothein B in plant materials by HPLCDAD-MS: method development and validation. Phytochem. Anal. 23, 582-587 http://dx.doi.org/10.1002/pca.2358

Haigis M. C., Guarente L. P. (2006): Mammalian sirtuins--emerging roles in physiology, aging, and calorie restriction. Genes Dev. 20, 2913-2921 http://dx.doi.org/10.1101/gad.1467506

Hevesi Toth B., Blazics B., Kery A. (2009): Polyphenol composition and antioxidant capacity of Epilobium species. J. Pharm. Biomed. Anal. 49, 26-31 http://dx.doi.org/10.1016/j.jpba.2008.09.047

Jenkins R. H., Thomas G. J., Williams J. D., Steadman R. (2004): Myofibroblastic differentiation leads to hyaluronan accumulation through reduced hyaluronan turnover. J. Biol. Chem. 279, 41453-41460 http://dx.doi.org/10.1074/jbc.M401678200

Karonen M., Parker J., Agrawal A., Salminen J. P. (2010): First evidence of hexameric and heptameric ellagitannins in plants detected by liquid chromatography/electrospray ionisation mass spectrometry. Rapid Commun. Mass Spectrom. 24, 3151-3156 http://dx.doi.org/10.1002/rcm.4756

Kim S. Y., Kim S. J., Lee J. Y., Kim W. G., Park W. S., Sim Y. C., Lee S. J. (2004): Protective effects of dietary soy isoflavones against UV-induced skin-aging in hairless mouse model. J. Am. Coll. Nutr. 23, 157-162

Kim Y. H., Kim K. H., Han C. S., Yang H. C., Park S. H., Jang H. I., Kim J. W., Choi Y. S., Lee N. H. (2010): Anti-wrinkle activity of Platycarya strobilacea extract and its application as a cosmeceutical ingredient. J. Cosmet. Sci. 61, 211-224

Kiss A., Kowalski J., Melzig M. F. (2004): Compounds from Epilobium angustifolium inhibit the specific metallopeptidases ACE, NEP and APN. Planta Med. 70, 919-923 http://dx.doi.org/10.1055/s-2004-832617

Kiss A. K., Bazylko A., Filipek A., Granica S., Jaszewska E., Kiarszys U., Kosmider A., Piwowarski J. (2011): Oenothein B's contribution to the anti-inflammatory and antioxidant activity of Epilobium sp. Phytomedicine 18, 557-560 http://dx.doi.org/10.1016/j.phymed.2010.10.016

Kopaskova M., Hadjo L., Yankulova B., Jovtchev G., Galova E., Sevcovicova A., Mucaji P., Miadokova E., Bryant P., Chankova 
S. (2011): Extract of Lillium candidum L. can modulate the genotoxicity of the antibiotic zeocin. Molecules 17, 80-97 http://dx.doi.org/10.3390/molecules17010080

Krejcova D., Prochazkova J., Kubala L., Pachernik J. (2009): Modulation of cell proliferation and differentiation of human lung carcinoma cells by the interferon-alpha. Gen. Physiol. Biophys. 28, 294-301

http://dx.doi.org/10.4149/gpb_2009_03_294

Ksiazek K., Mikula-Pietrasik J., Korybalska K., Dworacki G., Jorres A., Witowski J. (2009): Senescent peritoneal mesothelial cells promote ovarian cancer cell adhesion: the role of oxidative stress-induced fibronectin. Am. J. Pathol. 174, 1230-1240 http://dx.doi.org/10.2353/ajpath.2009.080613

Kumazaki T., Mitsui Y. (1995): Enhanced expression of fibronectin during cellular aging of endothelial cells and fibroblasts. Nihon Ronen Igakkai Zasshi 32, 322-325 (in Japanese)

Laga A. C., Murphy G. F. (2009): The translational basis of human cutaneous photoaging: on models, methods, and meaning. Am. J. Pathol. 174, 357-360 http://dx.doi.org/10.2353/ajpath.2009.081029

Lee B. Y., Han J. A., Im J. S., Morrone A., Johung K., Goodwin E. C., Kleijer W. J., DiMaio D., Hwang E. S. (2006): Senescenceassociated beta-galactosidase is lysosomal beta-galactosidase. Aging Cell 5, 187-195 http://dx.doi.org/10.1111/j.1474-9726.2006.00199.x

Ley R. D. (1985): Photoreactivation of UV-induced pyrimidine dimers and erythema in the marsupial Monodelphis domestica. Proc. Natl. Acad. Sci. U.S.A. 82, 2409-2411 http://dx.doi.org/10.1073/pnas.82.8.2409

Lin C. W., Hou W. C., Shen S. C., Juan S. H., Ko C. H., Wang L. M., Chen Y. C. (2008): Quercetin inhibition of tumor invasion via suppressing PKC delta/ERK/AP-1-dependent matrix metalloproteinase- 9 activation in breast carcinoma cells. Carcinogenesis 29, 1807-1815 http://dx.doi.org/10.1093/carcin/bgn162

Lin L. Z., Harnly J. M. (2007): A screening method for the identification of glycosylated flavonoids and other phenolic compounds using a standard analytical approach for all plant materials. J. Agric. Food Chem. 55, 1084-1096 http://dx.doi.org/10.1021/jf062431s

Lu L., Song F. R., Tsao R., Jin Y. R., Liu Z. Q., Liu S. Y. (2009): Studies on the homolytic and heterolytic cleavage of kaempferol and kaempferide glycosides using electrospray ionization tandem mass spectrometry. Rapid Commun. Mass Spectrom. 24, 169-172 http://dx.doi.org/10.1002/rcm.4368

Miadokova E., Chalupa I., Vlckova V., Sevcovicova A., Nadova S., Kopaskova M., Hercegova A., Gasperova P., Alfoldiova L., Komjatiova M., Csanyiova Z., Galova E., Cellarova E., Vlcek D. (2010): Genotoxicity and antigenotoxicity evaluation of nonphotoactivated hypericin. Phytother. Res. 24, 90-95 http://dx.doi.org/10.1002/ptr.2901

Neaud V., Rosenbaum J. (2008): A red wine polyphenolic extract reduces the activation phenotype of cultured human liver myofibroblasts. World J. Gastroenterol. 14, 2194-2199 http://dx.doi.org/10.3748/wjg.14.2194

Notas G., Nifli A. P., Kampa M., Pelekanou V., Alexaki V. I., Theodoropoulos P., Vercauteren J., Castanas E. (2012): Quercetin accumulates in nuclear structures and triggers specific gene expression in epithelial cells. J. Nutr. Biochem. 23, 656-666 http://dx.doi.org/10.1016/j.jnutbio.2011.03.010

Ouhtit A., Ananthaswamy H. N. (2001): A model for UV-induction of skin cancer. J. Biomed. Biotechnol. 1, 5-6 http://dx.doi.org/10.1155/S1110724301000031

Peng W. H., Tien Y. C., Huang C. Y., Huang T. H., Liao J. C., Kuo C. L., Lin Y. C. (2010): Fraxinus rhynchophylla ethanol extract attenuates carbon tetrachloride-induced liver fibrosis in rats via down-regulating the expressions of uPA, MMP-2, MMP-9 and TIMP-1. J. Ethnopharmacol. 127, 606-613 http://dx.doi.org/10.1016/j.jep.2009.12.016

Pfaffl M. W., Tichopad A., Prgomet C., Neuvians T. P. (2004): Determination of stable housekeeping genes, differentially regulated target genes and sample integrity: BestKeeper--Excel-based tool using pair-wise correlations. Biotechnol. Lett. 26, 509-515 http://dx.doi.org/10.1023/B:BILE.0000019559.84305.47

Quideau S. (2004): Plant „polyphenolic“ small molecules can induce a calorie restriction-mimetic life-span extension by activating sirtuins: will „polyphenols“ someday be used as chemotherapeutic drugs in Western medicine? Chembiochem. 5, 427-430 http://dx.doi.org/10.1002/cbic.200300835

Ruszova E., Pavek S., Hajkova V., Jandova S., Velebny V., Papezikova I., Kubala L. (2008): Photoprotective effects of glucomannan isolated from Candida utilis. Carbohydr. Res. 343, 501-511 http://dx.doi.org/10.1016/j.carres.2007.11.010

Sanchez-Rabaneda F., Jauregui O., Casals I., Andres-Lacueva C., Izquierdo-Pulido M., Lamuela-Raventos R.M. (2003): Liquid chromatographic/electrospray ionization tandem mass spectrometric study of the phenolic composition of cocoa (Theobroma cacao). J. Mass Spectrom. 38, 35-42 http://dx.doi.org/10.1002/jms.395

Scheck A. C., Perry K., Hank N. C., ClarkW. D. (2006): Anticancer activity of extracts derived from the mature roots of Scutellaria baicalensis on human malignant brain tumor cells. BMC Complement. Altern. Med. 6, 27 http://dx.doi.org/10.1186/1472-6882-6-27

Slavikova H., Lojek A., Hamar J., Duskova M., Kubala L., Vondracek J., Ciz M. (1998): Total antioxidant capacity of serum increased in early but not late period after intestinal ischemia in rats. Free Radic. Biol. Med. 25, 9-18 http://dx.doi.org/10.1016/S0891-5849(98)00030-6

Song J. J., Aswad R., Kanaan R. A., Rico M. C., Owen T. A., Barbe M. F., Safadi F. F., Popoff S. N. (2007): Connective tissue growth factor (CTGF) acts as a downstream mediator of TGF-beta1 to induce mesenchymal cell condensation. J. Cell Physiol. 210, 398-410 http://dx.doi.org/10.1002/jcp.20850

Sorg O., Janer V., Antille C., Carraux P., Leemans E., Masgrau E., Saurat J. H., Salomon D. (2007): Effect of intense pulsed-light exposure on lipid peroxides and thymine dimers in human skin in vivo. Arch. Dermatol. 143, 363-366 http://dx.doi.org/10.1001/archderm.143.3.363

Talhouk R. S., Karam C., Fostok S., El-Jouni W., Barbour E. K. (2007): Anti-inflammatory bioactivities in plant extracts. J. Med. Food 10, 1-10 http://dx.doi.org/10.1089/jmf.2005.055 
Tsuji M., Yamamoto H., Sato T., Mizuha Y., Kawai Y., Taketani Y., Kato S., Terao J., Inakuma T., Takeda E. (2009): Dietary quercetin inhibits bone loss without effect on the uterus in ovariectomized mice. J. Bone Miner. Metab. 27, 673-681 http://dx.doi.org/10.1007/s00774-009-0088-0

Vistejnova L., Dvorakova J., Hasova M., Muthny T., Velebny V., Soucek K., Kubala L. (2009): The comparison of impedancebased method of cell proliferation monitoring with commonly used metabolic-based techniques. Neuro. Endocrinol. Lett. 30 (Suppl. 1), 121-127

Vitalone A., Guizzetti M., Costa L. G., Tita B. (2003a): Extracts of various species of Epilobium inhibit proliferation of human prostate cells. J. Pharm. Pharmacol. 55, 683-690 http://dx.doi.org/10.1211/002235703765344603

Vitalone A., McColl J., Thome D., Costa L. G., Tita B. (2003b): Characterization of the effect of Epilobium extracts on human cell proliferation. Pharmacology 69, 79-87 http://dx.doi.org/10.1159/000072360

Wagner J. K., Jovel C., Norton H. L., Parra E. J., Shriver M. D. (2002): Comparing quantitative measures of erythema, pigmentation and skin response using reflectometry. Pigment Cell Res. 15, 379-384 http://dx.doi.org/10.1034/j.1600-0749.2002.02042.x

Wenk J., Schuller J., Hinrichs C., Syrovets T., Azoitei N., Podda M., Wlaschek M., Brenneisen P., Schneider L. A., Sabiwalsky A., et al. (2004): Overexpression of phospholipid-hydroperoxide glutathione peroxidase in human dermal fibroblasts abrogates UVA irradiation-induced expression of interstitial collagenase/ matrix metalloproteinase-1 by suppression of phosphatidylcholine hydroperoxide-mediated NFkappaB activation and interleukin-6 release. J. Biol.Chem. 279, 45634-45642 http://dx.doi.org/10.1074/jbc.M408893200

Yu A. L., Fuchshofer R., Kook D., Kampik A., Bloemendal H., Welge-Lussen U. (2009): Subtoxic oxidative stress induces senescence in retinal pigment epithelial cells via TGF-beta release. Invest. Ophthalmol. Vis. Sci. 50, 926-935 http://dx.doi.org/10.1167/iovs.07-1003

Received: October 23, 2012

Final version accepted: January 17, 2013 
Supporting information

\section{Epilobium angustifolium preparation reveals multiple effects on dermal fibroblasts in vitro and skin photo-protection}

Ema Ruszová ${ }^{1,2,3}$, José Cheel $^{1}$, Stanislav Pávek ${ }^{1}$, Martina Moravcová ${ }^{1}$, Martina Hermannová1, Ilona Matějková ${ }^{1}$, Jiřina Spilková4, Vladimír Velebný ${ }^{1}$ and Lukáš Kubala ${ }^{5,6}$

${ }^{1}$ Contipro Biotech s.r.o., Dolni Dobrouc, Czech Republic

${ }^{2}$ Department of Physiology and Immunology of Animals, Institute of Experimental Biology, Faculty of Science, Masaryk University, Kotlarska 2, Brno, Czech Republic

${ }^{3}$ Department of Clinical Genetics, Faculty Hospital, Sokolska 581, Hradec Kralove, Czech Republic

${ }^{4}$ Department of Pharmacognosy, Faculty of Pharmacy, Charles University, Heyrovskeho 1203, Hradec Kralove, Czech Republic

${ }^{5}$ Institute of Biophysics, Academy of Sciences of the Czech Republic, Kralovopolska 135, Brno, Czech Republic

${ }^{6}$ International Clinical Research Center - Center of Biomolecular and Cellular Engineering, St. Anne's University Hospital, Brno, Czech Republic

A
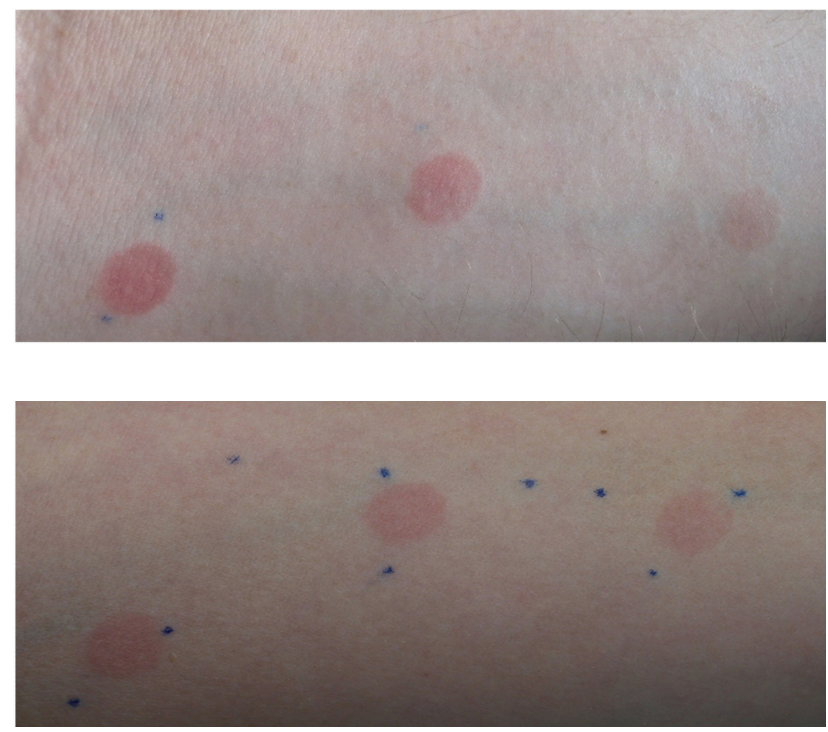

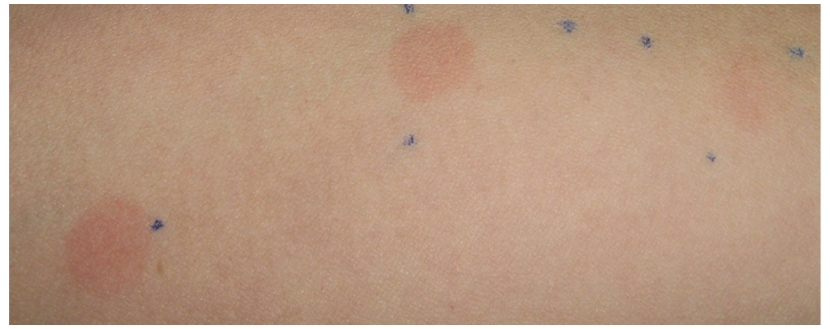

Figure 1S. EA extract reduced skin erythema induced by UV (1.25 MED). Typical results of erythema skin formation shown on 3 volunteers. Experiments were performed as described in the section Materials and Methods. A. Reference test site (non-treated). B. Test site treated with solvent (3\%) in carbomer gel. C. Test site treated with $E A$ extract (3\%) in carbomer gel. 